\title{
Ratio of Professional to Clerical Staff
}

"T HE RECOGNITION of the fact that a large proportion of the activities of the university library consists of routines that can be performed by instructed clerical workers should eventually lead to the concentration of professional effort upon major problems of reading, scholarship, and research. Within the limits of the individual library's definition of 'clerical worker,' the situation seems to indicate that many libraries are using professionally trained personnel to perform clerical or subprofessional tasks."1

The authors of the above statement may have hoped for some immediate reaction on the part of administrators in our major universities. Such has not been the case. There have been studies made from time to time pointing toward the possibility of more careful definition of duties and responsibilities, but positive action has occurred in only a few institutions.

Perhaps many institutions have been aware of having a high ratio of professional staff but have seen no immediate way to alter the situation without injustice to persons who had established tenure. Others may never have readjusted from the exigencies of depression years when staff reduction first affected certain clerical positions. In some of the larger institutions, a proliferation of departmental libraries has often been the reason assigned for the size of professional staff required. Whatever the reason, it seems likely that librarians facing financial pressures may need to scrutinize care-

${ }^{1}$ L. R. Wilson and M. F. Tauber, The University Library (Chicago: University of Chicago Press, 1945), 247.

Dr. McNeal is director of libraries, University of Miami. fully the nature of personnel required to perform the duties of each position. Proper job analysis and classification of positions is essential to such a survey.

Some idea of the progress being made can be secured from a comparison of certain data in Wilson and Tauber's original table with similar data developed from other sources for subsequent years (see the accompanying table). When the sources used did not contain data for institutions listed in the 1940 table, every effort was made to secure such information by correspondence. In some cases, it was not possible to obtain the information requested.

It is evident that a trend toward a higher ratio of clerical to professional staff is developing but it cannot be assumed that this is a purposeful trend. Rather, it is more likely a result of growth, and of necessity imposed by the increasing demand for professional librarians.

The ratio between clerical and professional staff given in $A L A$ Classification and Pay Plans for Libraries in Institutions of Higher Education is established on the following basis: ". . . there shall be clerical and student workers sufficient to assure that not more than 60 per cent or less than 40 per cent of total staff hours shall be clerical or student service." 2 Such a provision means that an institution with 20 full-time staff positions should have no more than 12 nor less than 8 full-time clerical workers, or the equivalent in clerical and student help.

\footnotetext{
ALA Board on Personnel Administration. Subcom. mittee on Budgets, Compensation and Schemes of Service for Libraries Connected with Universtities, Colleges and Teacher Training. Institutions. Classification and Pay Plans in Institutions of Higher Education (2d ed.; Chicago: American Library Association, 1947), III, p. xxiv.
} 
Ratio of Professional to Other Types of Workers in 50 University Libraries, 1940-54

\begin{tabular}{|c|c|c|c|c|c|c|c|c|c|c|c|c|}
\hline \multirow[b]{2}{*}{ Harvard } & Prof. C & OTHER & $40^{1}$ & $\begin{array}{c}\% \\
\text { PROF. }\end{array}$ & Prof. & 194 & $48^{2}$ & $\begin{array}{c}\% \\
\text { PROF. }\end{array}$ & Prof. & 19 & $54^{3}$ & $\begin{array}{l}\text { PROF. } \\
\text { PRo }\end{array}$ \\
\hline & $\begin{array}{ll}51.8 & 1\end{array}$ & 117.65 & 169.45 & 30.5 & 56.2 & 151.7 & 207.9 & 27.0 & 137.33 & 220.67 & 358.0 & 38.3 \\
\hline New York U. & 34.0 & 76.0 & 110.0 & 30.9 & 44.0 & 96.0 & 140.0 & 31.4 & 36.0 & 91.0 & 127.0 & 28.3 \\
\hline Pennsylvania & 21.0 & 35.0 & 56.0 & 37.5 & 31.0 & 58.0 & 89.0 & 34.8 & 55.0 & 99.0 & 154.0 & 35.7 \\
\hline Dartmouth & 24.0 & 34.0 & 58.0 & 41.4 & 29.0 & 37.0 & 66.0 & 43.9 & 34.5 & 33.5 & 68.0 & 50.7 \\
\hline Virginia & 23.0 & 32.0 & 55.0 & 41.8 & 25.0 & 36.0 & 61.0 & 40.9 & 29.0 & 40.0 & 69.0 & 42.0 \\
\hline Pittsburgh & 19.0 & 26.5 & 45.5 & 41.8 & 17.5 & 32.0 & 49.5 & 35.3 & 20.0 & 28.0 & 48.0 & 41.7 \\
\hline Catholic U. & 8.0 & 11.0 & 19.0 & 42.1 & & & & & 18.0 & 20.0 & 38.0 & 47.3 \\
\hline Brown & 24.34 & 29.34 & 53.68 & 45.3 & 26.8 & 52.0 & 78.8 & 34.0 & 21.0 & 37.0 & 58.0 & 36.2 \\
\hline Yale & 72.0 & 85.0 & 157.0 & 45.9 & 57.1 & 85.1 & 142.2 & 40.1 & 103.5 & 132.5 & 236.0 & 43.8 \\
\hline Princeton & 32.0 & 37.0 & 69.0 & 46.4 & 26.33 & 60.67 & 87.0 & 30.2 & 28.66 & 84.0 & 112.66 & 25.4 \\
\hline $\begin{array}{l}\text { Vashington } \\
\text { (Seattle) }\end{array}$ & & 36.5 & 6 & 46.7 & 37.9 & 80.5 & 118.4 & 32.0 & 46.75 & 70.5 & 117.25 & 39.8 \\
\hline Utah & 12.0 & 13.0 & 25.0 & 48.0 & & & & & 19.0 & 25.0 & 44.0 & 43.2 \\
\hline Rochester & 21.0 & 22.0 & 43.0 & 48.8 & 27.0 & 19.0 & 46.0 & 58.7 & 26.5 & 28.5 & 55.0 & 48.1 \\
\hline Co & $114.4 \quad 1$ & 117.4 & 23 & 49.4 & 111.0 & $244.0^{\circ}$ & $355.0^{6}$ & 31.2 & 89.0 & $227.0^{8}$ & $316.0^{8}$ & 27.1 \\
\hline We & 10.0 & 10.0 & 20.0 & 50.0 & & & & & & & & \\
\hline Cincinnati & 17.0 & 18.5 & 35.5 & 50.7 & 23.0 & 18.0 & 41.0 & $56: 1$ & 17.0 & 30.5 & 47.5 & 35.7 \\
\hline Iow & 0 & 15.0 & 32.0 & 53.1 & 15.0 & 37.0 & 52.0 & 28.8 & 30.75 & 47.75 & 78.5 & 39.1 \\
\hline $\mathrm{Te}$ & & 14.41 & 32.41 & 55.5 & 22.5 & 17.0 & 39.5 & 56.9 & 33.0 & 25.0 & 58.0 & 56.9 \\
\hline estern & 25.0 & 20.0 & 45.0 & 55.6 & 33.0 & 33.5 & 66.5 & 49.6 & 45.0 & 53.0 & 98.0 & 45.9 \\
\hline Southern Cal. & 30.0 & 20.0 & 50.0 & 60.0 & 41.0 & 33.0 & 74.0 & 55.4 & 34.0 & 43.0 & 77.0 & 44.1 \\
\hline Duke & 3 & 23.0 & 58.0 & 60.3 & 37.5 & 33.5 & 71.0 & 52.8 & 37.25 & 42.25 & 79.5 & 46.8 \\
\hline go & 63.425 & 34.85 & 98.275 & 64.5 & 63.0 & $135.0^{6}$ & 198.0 & 31.8 & 51.0 & $82.0^{\circ}$ & 133.0 & 38.3 \\
\hline W & 11.0 & 6.0 & 17.0 & 64.7 & 18.5 & 15.5 & 34.0 & 54.4 & 26.63 & 34.62 & 61.25 & 43.4 \\
\hline Notre Dame & 11.0 & 6.0 & & 64.7 & 16.0 & 12.0 & 28.0 & 57.1 & 17.0 & 20.0 & 37.0 & 45.9 \\
\hline Texas & 38 & 18.0 & 8 & 65.5 & 40.9 & 22.0 & 62.9 & 65.0 & 43.8 & 0 & 78.8 & 55.5 \\
\hline We & 8.0 & 7.0 & 15 & 66.7 & 10.5 & 9.0 & 19.5 & 3.8 & 22.0 & 30.0 & 52.0 & 42.3 \\
\hline Mary & 12.0 & 6.0 & 18.0 & 66.7 & 19.0 & 10.0 & 29.0 & 65.5 & 25.0 & 16.5 & 41.5 & 60.2 \\
\hline Geo & 18.0 & 9.0 & 27.0 & 66.7 & 19.0 & 16.5 & 35.5 & 53.5 & 26.5 & 25.5 & 52.0 & 53.5 \\
\hline $\begin{array}{r}\text { Was } \\
\text { (S }\end{array}$ & & 5.0 & & 0 & 13.0 & 17.0 & 30.0 & 43.3 & 19.0 & 36.0 & 55.5 & 35.1 \\
\hline St. I & 11.5 & 5.0 & 16. & 69.7 & 16.0 & 20.0 & 36.0 & 44.4 & 17.0 & 24.0 & 41.0 & 41.4 \\
\hline Cali & 53.5 & 22.84 & 76.34 & 70.0 & 93.0 & 97.75 & 190.75 & 48.7 & 126.75 & 173.0 & 299.25 & 42.1 \\
\hline Inc & 18 & 5.0 & 17.0 & 70.6 & 41.0 & 26.0 & 67.0 & 61.2 & 40.0 & 53.5 & 93.5 & 42.7 \\
\hline & 26.5 & 16.25 & 42.75 & 72.0 & 36.25 & 21.0 & 57.25 & 63.3 & 57.0 & 25.0 & 82.0 & 69.5 \\
\hline Nebi & 19.5 & 7.0 & 26.5 & 73.6 & 33.0 & 16.50 & 49.50 & 66.6 & 34.5 & 30.5 & 65.0 & 53.0 \\
\hline Ore & .74 & 8.25 & 28.99 & 74.0 & 24.13 & 13.85 & 37.98 & 63.5 & 5 & 26.25 & 54.75 & 52.0 \\
\hline Joi & 26.5 & 8.5 & & 75.7 & 27.0 & 11.5 & 38.5 & 70.1 & 26.0 & 14.5 & 40.5 & 64.1 \\
\hline & 88.5 & 26.5 & 115.0 & 77.0 & 108.0 & 30.0 & 138.0 & 78.2 & 102.5 & 51.0 & 153.5 & 66.7 \\
\hline a (L.A & 35.0 & 10.0 & 45.0 & 77.8 & 42.0 & 25.0 & 67.0 & 62.6 & 80.0 & 85.0 & 165.0 & 48.4 \\
\hline Okl & 12.0 & 3.0 & 15.0 & 80.0 & 13.0 & 6.0 & 19.0 & 68.4 & 29.0 & 23.0 & 52.0 & 68.4 \\
\hline Miss & 24.0 & 6.0 & 30.0 & 80.0 & 20.5 & 18.0 & 38.5 & 53.2 & 21.0 & 20.0 & 41.0 & 51.2 \\
\hline Ior & 43.5 & 9.5 & 53.0 & 82.1 & 31.5 & 17.5 & 49.0 & 64.3 & 30.75 & 47.75 & 78.5 & 39.1 \\
\hline Illinois & 94.5 & 20.0 & 114.5 & 82.5 & 129.26 & 72.05 & 201.31 & 64.2 & 132.0 & 110.75 & 242.75 & 54.3 \\
\hline Arkansa & 15.0 & 3.0 & 18.0 & 83.3 & 12.75 & 8.0 & 20.75 & 61.4 & 17.0 & 11.0 & 28.0 & 60.7 \\
\hline Ken & 14.0 & 2.5 & 16.5 & 84.8 & 18.0 & 15.5 & 33.5 & 53.7 & 28.0 & 26.0 & 54.0 & 51.8 \\
\hline Kan & 17.0 & 3.0 & 20.0 & 85.0 & 21.0 & 9.0 & 30.0 & 70.0 & 37.25 & 27.25 & 64.5 & 57.7 \\
\hline Colorado & 20.0 & 3.0 & 23.0 & 87.0 & 17.0 & 11.0 & 28.0 & 60.7 & 20.0 & 18.0 & 38.0 & 52.6 \\
\hline Pen & & & & & & & & & & & & \\
\hline & & 2.0 & 26.0 & 92.3 & 28.0 & 22.0 & 50.0 & 56.0 & Une. & 8.0 & 66.0 & 48.4 \\
\hline Ore & 21.88 & 1.5 & 23.38 & 93.5 & 23.58 & 13.32 & 36.9 & 63.9 & 24.33 & 16.33 & 40.66 & 59.8 \\
\hline Syracuse & & 2.0 & 37.0 & 94.6 & 38.5 & 22.0 & 60.5 & 63.6 & 34.25 & 29.5 & 63.75 & 53.7 \\
\hline Louisiana & 41.0 & 2.0 & 43.0 & 95.3 & 33.5 & 24.0 & 57.5 & 58.2 & 47.0 & 30.0 & 77.0 & 61.1 \\
\hline
\end{tabular}

1 Wilson and Tauber, The University Library, 1945, p. 230.

2 COLLEGE AND RESEARCH LIBRARIES, IX (1948), 239.

8 COLLEGE AND RESEARCH LIBRARIES, XVI (1955), 41

4 No indication whether student assistants included or excluded.

Specifically excludes student assistants.

${ }^{6}$ Includes student assistants. 
In the introduction to the second edition, the following statement appears: "Standards for libraries in institutions of higher education vary greatly in different parts of the country. Therefore the personnel standards used in the national pattern are necessarily at variance with local conditions in some institutions. It is felt, after considerable testing, that they do reflect average conditions throughout the country."3

So far as can be determined, from internal evidence cited above, and from conversation with a former chairman of the subcommittee, the basis for establishing the ratio of clerical to professional staff was that then existing in a majority of institutions surveyed. While the document provided goals and offered desirable conditions in many respects, it accepted the status quo on this particular point. Such acceptance would not be unfortunate, were it not for the misinterpretation by some who have used the ratio as a rule without reading the statement in the Introduction. Perhaps the new edition will give some attention to this problem.

The decision to lump clerical and student assistance in one category seems questionable. Admittedly, many excellent student helpers are developed and often their usefulness is greater than that of an inferior full-time clerical worker. However, it is an inescapable fact that the turnover in this type of worker necessitates constant training of replacements, so it would seem desirable to have clerical workers, suitably classified and paid, as a separate category. Thus, with an effective professional staff, a reasonable number of clerical personnel, and student assistants as available and needed, there would be a much sounder personnel program, and evaluation would be simplified.

The need for an additional category classed "subprofessional" was ruled out by the ALA subcommittee in their plans

Ibid., pp. xiii, xiv. referred to above, but received careful attention by Williams in $1954 .{ }^{4}$ At that time he suggested: "It might be reasonable to expect that an administrator who wished to keep the percentage of professional members on his staff as low as possible would find it desirable to employ some nonprofessional persons of a higher grade than would be needed in an institution where librarians were doing much of the clerical work." While Williams did not consider the term "subprofessional" satisfactory, he did recognize the need for some intermediate grade falling between the professional librarian and the page-typist-filer group. ${ }^{5}$

Whether we consider Danton's proposal for three levels of library service, technical or subprofessional, middle service, and administrative-specialist ${ }^{6}$ or something similar to the German middle service as described by Cowley, ${ }^{7}$ who contrasts the "theoreticalists" and the "practicalists," there would seem to be a place in libraries of institutions of higher education for the well-educated library assistant who has developed certain proficiencies on the job. The matter of formal library school training for such a middle service might well be the subject for another article, and has been given some detailed consideration by McDiarmid. 8

Many libraries find on their staff persons of superior educational qualifications who for various reasons have not determined to secure a library degree. Many of these persons have particular abilities which, as they develop under professional supervision, enable them to function at a level above the routine

\footnotetext{
Edwin E. Williams, "Who Does What: Unprofessional Personnel Problems," college aND RESEARCH LIBRARIES, VI (1945), 306.

5 Ibid.

- J. P. Danton, Education for Librarianship; Criticisms, Dilemmas, and Proposals (New York: Columbia University School of Library Service, 1946).

7 John D. Cowley, "The Development of Professional Training for Librarianship in Europe," Library Quarterly, VII (1937), 169-95.

8 Errett W. McDiarmid, "Training of Clerical and Subprofessional Workers," in Chicago. University Graduate Library School. Library Conference, Education for Librarianship (Chicago: American Library tion for Librarianship (Chociation, 1949), 232-48.
} 
clerical tasks. In-service training programs can further develop these persons and frequently may discover in them prospective recruits to professional training. In other cases, the individual may develop to such an extent that he occupies a major position without having experienced any formal library school training. Certainly some of our bestknown and most effective librarians have entered the profession without benefit of the midwifery of the library school. This is not to say that such a procedure is advocated, nor is it in any sense intended to detract from the importance of formal training. Rather, it is a plea for those special cases where ability and application merit recognition.

At this point it might be well to estimate the disadvantages attendant upon entry into the library profession without formal library school training. There is the time factor which usually operates in favor of the degree-qualified person and becomes apparent in salary differentials. There is the danger of in-breeding, to the extent that one coming up through the ranks in one institution is compressed into the mold of that library's philosophy and method. It is possible that such a person may be limited to one sphere of activity and become very capable in it, but be entirely devoid of training or knowledge of other areas.

In spite of these dangers, many libraries now have on their staff individuals who perform their duties with professional skill, and think and act in a professional manner. Such staff members may well be considered for equal compensation, as well as for equal consideration in matters of vacation, retirement, and similar matters, so far as the charter of the institution permits.

In addition to the person who may be considered a "career" individual among the nonprofessionals, there are others who merit our attention. The worker whose husband is attending school or who seeks to supplement the income of a husband employed locally may have qualifications in terms of education and training that enable her to rise to near-professional performance during the years she will work. Such a person justifies time spent on her during the period of training, and deserves recognition as her experience increases.

For persons such as this, it is suggested that we look back to the days of the library training class. We ought to think in terms of in-service training today for those who can not or will not leave to spend a year in library school. It is not proposed that this type of assistance be substituted for professional librarians where professionals are needed, but rather that we supplement the professional with superior nonprofessional assistants whose experience warrants recognition.

Williams suggested that a real shortage of professional librarians might result in the maximum use of personnel resources, with clerical personnel being called upon to perform the maximum possible in duties of a clerical nature. Leigh found in his survey of California that such a shortage did exist in 1952.9 Evidence from library schools indicates that there were from three to five jobs for each graduate in 1954 .

Weber, in a recent article on the clerical staff, pointed out factors responsible for a new concern over this group: "First, the growing demand for library service of all kinds, challenging the planning skills of all librarians; second, the rising costs of operation . . . ; third, the shortage of qualified professional personnel, making it imperative to use the available supply to the best advantage." 10 We seem to be at a point now where the administrator might well give careful attention to his staff organization in terms of the ALA Descriptive List of Professional and Nonprofessional Duties in Libraries.

${ }^{9}$ Robert D. Leigh, The California Librarian Education Survey (New York: Columbia University, 1952), 14.

io Dorothy Weber, "The Clerical Staff," Library Trends III (1954), 53. 
As suggested in an earlier article, ${ }^{11}$ it seems practical to assume that one professional to two clerical staff members might approximate a desirable ratio. It is interesting to see that in Williams' figures for 1940-41, disregarding student assistance, only Harvard met this ideal; Pennsylvania and Oberlin approached it. Today, we find that New York University and Princeton operate on the proposed basis. Harvard, Cincinnati, Brown, Pennsylvania, Iowa, Iowa State and Washington University are among those which have less than 40 per cent professional librarians on their staffs.

This proportion is suggested with regard to full-time staff. Student assistance is used to a greater or lesser degree as local conditions vary. In many cases, it is used of necessity. Where choice is possible, it would seem desirable to use student assistants for those tasks best suited to their abilities and to their part-time availability. In every case where tasks could be performed equally well by fulltime clerical personnel, it would seem desirable to convert the necessary parttime components to a full-time position, thus giving the supervisory personnel one instead of three or four persons to train and schedule.

11 A. L. McNeal, "Financial Problems of University Libraries," COLLEGE AND RESEARCH LIBRARIES, XV (1954), 410 .

\section{Nominees for ALA Offices}

The ALA Nominating Committee is anxious to receive as widespread cooperation as possible from all members of the Association in suggesting names to be considered for the various elective offices. Recommendations for first vice president and president-elect, second vice president, and members of the executive board and the council are solicited, and may be sent to the chairman of the committee, Foster E. Mohrhardt, director of the Department of Agriculture Library, Washington, D. C.
In summary, it is proposed that administrators consider the duties of the professional members of their staff, and attempt to utilize professional competence in the performance of work that will challenge and lead to further development of professional skill. Just as the repetitious phrases in a second-grade reader dull the interest and enthusiasm of an experienced reader, so will the assignment of clerical routine stultify the energetic professional librarian.

It is further proposed that the subprofessional be nurtured and encouraged, and that this group be given such training and advancement as may be possible. Recruitment interests can of ten be served through observant utilization of special skills within this category.

Finally, the clerical staff, properly assigned and properly supervised, can accomplish effectively and efficiently much more than it is permitted to do in many libraries. Proper delegation of responsibility, with commensurate authority, is essential to good staff organization. Likewise, it is important that the clerical workers be given recognition for good work. Their morale can be strengthened by the feeling that they "belong" and are an essential factor in the accomplishment of the library program.

\section{Conference Placement Service}

During the Miami Beach Conference, a simplified contact placement clearing house will be available to employers and to librarians interested in changing positions. An office will be provided where (1) employers may post notices of vacancies and leave messages for persons interested in vacancies, and (2) librarians interested in changing positions may see the posted vacancies, leave messages for employers, and post notices of their availability. Readers are referred to the May, 1956, ALA Bulletin for further details. 